\title{
Tripalladium(0) Sandwich Complexes with Nitrogen Based Ligands
}

John C. Charbonneau ${ }^{1}$, Cory B. Cluff ${ }^{2}$, Hannah R. Babbini ${ }^{3}$, Dominic C. Babbini ${ }^{3}$, Gary S. $\mathrm{Nichol}^{4}$ and Stephanie K. Hurst*1.

1 Department of Chemistry and Biochemistry, Northern Arizona University, Flagstaff, AZ, $86011-5698$

${ }^{2}$ School of Molecular Sciences, Arizona State University, Tempe, Arizona 85287-1604

${ }^{3}$ Department of Chemistry \& Biochemistry, 251 Nieuwland Science Hall, Notre Dame, IN 46556

${ }^{4}$ School of Chemistry, The University of Edinburgh, Edinburgh, United Kingdom, EH9 3FJ

Received: September 2015

Abstract: The synthesis and characterization of a series of complexes based upon a central tripalladium ditropylium (Tr) unit $\left[\mathrm{Pd}_{3} \mathrm{Tr}_{2}\right]^{2+}$ containing different nitrogen-based ligands is reported. The complexes were synthesized in good yield and characterized by multi-nuclei NMR spectroscopy, elemental microanalysis and single-crystal X-ray crystallography. Variation in the equatorial ligand strongly influences $\mathrm{Pd}-\mathrm{N}$ bond distances, but has only a minor effect on Pd-Pd distances. These complexes provide insight into the synthesis of materials of higher dimensionality.

Keywords: Tripalladium; Pyridine; Nitrile; Tropylium; Sandwich; 


\section{Introduction}

In addition to their great diversity of applications in catalysis, palladium complexes are also of great interest in the formation of large multi-dimensional coordination systems. These unique systems range from the macrocyclic ring systems, self-assembled polyhedra and pseudo-infinite arrays based upon metal-organic frameworks (MOF's), and these systems can achieve great molecular diversity through the application of a variety of "node" and "linker" systems. New metal-containing systems make excellent nodes by possessing properties of stability to environmental conditions, multiple coordination sites and coordination motifs. Stang and coworkers have demonstrated the utility of mono-palladium complexes to act as the core of selfassembling metallomacrocycles. ${ }^{1,2}$

The high surface areas and well-defined structures of MOF's make them promising molecular systems for a variety of applications including gas adsorption, gas storage, and catalysis. The key role of palladium in hydrogenation and other reactions (e.g. Suzuki-Miyaura coupling, Sonogashira coupling and other reactions) suggest that palladium MOF's may open a new window into catalytic active materials. Conventional sources of active palladium catalysts such as palladium stabilized by dibenzylideneacteone ligands $\left[\mathrm{Pd}_{2}(\mathrm{dba})_{3}\right]$ suffer from a number of drawbacks. Zero-valent palladium precursors are commonly sensitive to light, heat and oxidation and MOF's have been demonstrated to confer greater stability to environmental factors. ${ }^{3,4}$ The active zero-valent material undergoes rapid aggregation in solution with consequent loss of catalytic activity. ${ }^{5,6}$ Leaching of the catalytic material into the solution also requires additional clean up steps, and the ability to more effectively trap and stabilize the active metal catalyst would therefore provide a number of benefits. 
We have extensively studied one particular system that may be utility in the formation of extended network systems. In 2006 the synthesis of a novel trimetallic palladium(0) sandwich complex $\left[\mathrm{PPh}_{4}\right]\left[\mathrm{Pd}_{3} \mathrm{Tr}_{2} \mathrm{Cl}_{3}\right]$ was reported. ${ }^{7}$ This complex incorporated a triangular arrangement of palladium(0) atoms "sandwiched" between two tropylium (Tr) rings $\left(\mathrm{C}_{7} \mathrm{H}_{7}^{+}\right)$. Although both triangular and linear tripalladium(II) complexes have been reported previously, ${ }^{8-11}$ the stability and ease of ligand substitution on these sandwich complexes have given rise to the possibility of new substitution patterns and molecular motifs including the formation of network structures..

We have demonstrated that these complexes may incorporate a range of anionic and neutral ligands in the equatorial position, and may also utilize a wide range of countercations. ${ }^{12,13}$ In addition, we have shown that these complexes give rise to one-dimensional polymers consisting of $\left[\mathrm{Pd}_{3} \operatorname{Tr}_{2}\right]^{2+}$ units linked by bridging anionic ligands. Since 2008 we have been interested in investigating the effect of ligand substitution on the $\left[\mathrm{Pd}_{3} \mathrm{Tr}_{2}\right]^{2+}$ motif, as well as expanding this structural system to include a variety of metal centers including platinum. Our group has reported trimetallic complexes of palladium and platinum could be formed using the same methodology. ${ }^{14}$ Murahashi and coworkers have also subsequently reported the synthesis and characterization of the $\left[\mathrm{Pd}_{\mathrm{x}} \mathrm{Pt}_{3-\mathrm{x}} \mathrm{Tr}_{2}\right]^{2+}$ motif. ${ }^{15}$ Our group is interested in the formation of large network or dendrimeric structures that may also be possible after a greater understanding of the ligand binding motifs is developed. ${ }^{16-19}$ Herein we report the development of a series of zerovalent tripalladium sandwich complexes with nitrogen based ligand systems.

$<$ Scheme 1> 


\section{Results and Discussion}

Synthesis

Our group has previously reported the synthesis of a series of pnictogen complexes $\left[\mathrm{Pd}_{3} \operatorname{Tr}_{2}\left(\mathrm{XPh}_{3}\right)_{3}\right]\left[\left(\mathrm{BF}_{4}\right)_{2}\right](\mathrm{X}=\mathrm{N}, \mathrm{P}$ or $\mathrm{Sb})$ via the reaction of $\left[\mathrm{P}-n-\mathrm{Bu}_{4}\right]\left[\mathrm{Pd}_{3} \operatorname{Tr}_{2} \mathrm{Br}_{3}\right]$ with $\mathrm{AgBF}_{4}$ and an excess of $\mathrm{XPh}_{3}$ in dichloromethane. ${ }^{20}$ In certain reactions, use of silver tetrafluoroborate $\left(\mathrm{AgBF}_{4}\right)$ or silver triflate $\left(\mathrm{AgSO}_{3} \mathrm{CF}_{3}\right)$ did not lead to the expected homoleptic product, but rather a system containing both neutral ligands and counter anions bound to the metal centre. A large excess of the silver salt was employed to drive displacement of the halide ligand. In the present study, a salt metathesis reaction was carried out in which $\left[\mathrm{PBu}_{4}\right]\left[\mathrm{Pd}_{3} \operatorname{Tr}_{2} \mathrm{Br}_{3}\right]$ or $\left[\mathrm{PPh}_{4}\right]\left[\mathrm{Pd}_{3} \mathrm{Tr}_{2} \mathrm{Br}_{3}\right]$ was reacted with $\mathrm{AgBF}_{4}$ in neat pyridine to give a red-brown complex $\left[\mathrm{Pd}_{3} \operatorname{Tr}_{2}(\mathrm{Py})_{3}\right]\left[\left(\mathrm{BF}_{4}\right)_{2}\right]\left(\mathrm{Py}=\right.$ pyridine) (1a) $\left(\right.$ Scheme 1). ${ }^{1} \mathrm{H}$ NMR in $\mathrm{d}^{6}-\mathrm{DMSO}$ confirmed the uptake of the pyridine ligand, and the absence of any of the original $\left[\mathrm{PBu}_{4}\right]^{+}$counter-cation. Reaction in either neat pyridine or pyridine diluted with dichloromethane gave identical products. The retention of the $\left[\mathrm{Pd}_{3} \mathrm{Tr}_{2}\right]^{2+}$ unit was confirmed by ${ }^{1} \mathrm{H}$ NMR with a shift in the tropylium resonance from 4.72 in the precursor complex to $4.81 \mathrm{ppm}$ in 1a. Peaks consistent with the presence of residual DMSO solvent $(\sim 2.48 \mathrm{ppm})$ and water $(\sim 3.30 \mathrm{ppm})$ were also observed. The integration between the signals of the pyridine and tropylium peaks varies between samples, but confirms the expected formulation. No signals consistent with unreacted tropylium ( $\sim 9.2 \mathrm{ppm})$ were observed. The formation of the expected product was also confirmed by the absence of any signal in the ${ }^{31} \mathrm{P}$ NMR of the original phosphonium cation, and the appearance of the characteristic signal for the $\left[\mathrm{BF}_{4}\right]^{-}$anion at $-155.3 \mathrm{ppm}$ in the ${ }^{19} \mathrm{~F}$ NMR. Replacement of $\mathrm{AgBF}_{4}$ with $\mathrm{AgSO}_{3} \mathrm{CF}_{3}$ gave the analogous product $\left.\left[\mathrm{Pd}_{3} \operatorname{Tr}_{2}\left(\mathrm{Py}_{3}\right)_{3}\right]\left(\mathrm{SO}_{3} \mathrm{CF}_{3}\right)_{2}\right]$ $($ Py $=$ pyridine) (1b). The presence of the triflate counter-anion increased the solubility of the 
product and permitted data collection from chloroform and dichloromethane solutions. This overall formula was confirmed by CHN microanalysis as $\left[\mathrm{Pd}_{3} \operatorname{Tr}_{2}(\mathrm{Py})_{3}\right]\left[\left(\mathrm{BF}_{4}\right)_{2}\right](\mathrm{Py}=$ pyridine $)$ (1a) and $\left[\mathrm{Pd}_{3} \operatorname{Tr}_{2}(\mathrm{Py})_{3}\right]\left[\left(\mathrm{SO}_{3} \mathrm{CF}_{3}\right)_{2}\right](\mathbf{1 b})$ respectively.

The ${ }^{1} \mathrm{H}$ NMR spectrum between $6-8 \mathrm{ppm}$ in both $\mathbf{1 a}$ and $\mathbf{1 b}$ is similar to that of free pyridine, suggesting that in solution the pyridine ligands are labile and the available coordination sites contain weakly coordinated solvent molecules. The position of the tropylium peak occurs at 4.81 and $4.83 \mathrm{ppm}$ in $\mathbf{1 a}$ and $\mathbf{1 b}$ respectively, indicating that there is minimal effect from the anion on the ${ }^{1} \mathrm{H}$ NMR spectra. Recrystallization from dichloromethane and diethyl ether gave single crystals suitable for X-ray diffraction studies. Attempts to recrystallize 1a in acetonitrile for X-ray diffraction studies gave dark red plate-like crystals which were determined to be the acetonitrile substituted complex $\left[\mathrm{Pd}_{3} \operatorname{Tr}_{2}(\mathrm{MeCN})_{3}\right]\left[\left(\mathrm{BF}_{4}\right)_{2}\right]$ (2) (vide infra). This unanticipated ligand exchange may provide a new synthetic pathway for the creation of extended systems. Unlike the halogen substituted complexes such as $\left[\mathrm{Pd}_{3} \operatorname{Tr}_{2} \mathrm{Br}_{3}\right]^{-}$no evidence of the parent ion of 1a or $\mathbf{1 b}$ was observed by ion-trap mass spectrometry.

Attempts to synthesize and characterize a series of pyridine substituted tripalladium complexes were generally unsuccessful. Reactions with a range of pyridine derivatives with electro-withdrawing substituents including 4-nitropyridine and 4-fluoropyridine were attempted. ${ }^{1} \mathrm{H}$ NMR studies indicated that the ligand were not present in the final product, but that the $\left[\operatorname{Pd}_{3} \mathrm{Tr}_{2}\right]^{2+}$ unit was retained. Competition between the nitrogen-containing ligand and the counteranion is expected to complicate isolation of such derivatives, given the known affinity for "non-coordinating" anions including $\mathrm{BF}_{4}{ }^{-}$and $\mathrm{CF}_{3} \mathrm{SO}_{3}{ }^{-}$to bind to the $\left[\mathrm{Pd}_{3} \mathrm{Tr}_{2}\right]^{2+}$ unit. ${ }^{12,21}$

To further investigate the role of changing Lewis base strength, a similar displacement reaction was undertaken with 4-dimethylaminopyridine (DMAP) in dichloromethane. DMAP is 
a strong Lewis base which has significant utility in organic chemistry. Reaction of $\left[\mathrm{PPh}_{4}\right]\left[\mathrm{Pd}_{3} \operatorname{Tr}_{2} \mathrm{Br}_{3}\right]$ with $\mathrm{AgBF}_{4}$ and 4-dimethylaminopyridine in dichloromethane gave the new complex $\left[\mathrm{Pd}_{3} \operatorname{Tr}_{2}(\mathrm{DMAP})_{3}\right]\left[\left(\mathrm{BF}_{4}\right)_{2}\right](3)$, which was confirmed by $\mathrm{CHN}$ microanalysis and multinuclear NMR studies. Further investigations demonstrated that $\mathbf{3}$ could be also synthesized via an alternate synthetic route by reacting $\left[\mathrm{Pd}_{2}(4-\mathrm{MeO}-\mathrm{dba})_{3}\right]$ (4-MeO-dba $=4$-methoxydibenzylideneacetone) with $\mathrm{Tr} \cdot \mathrm{BF}_{4}$ and $\mathrm{DMAP}$ in dichloromethane at room temperature (Scheme 1).

${ }^{1} \mathrm{H}$ NMR studies on 3 indicate the presence of a single peak at $4.66 \mathrm{ppm}$ that is attributed to the tropylium protons in the product. A large singlet at $3.00 \mathrm{ppm}$ and can be attributed to protons on the dimethylamino moiety. Two sets of signals were centered at 6.68 and $7.95 \mathrm{ppm}$, and were attributed to the two unique hydrogen environments on the 4-dimethylaminopyridine ring. The signals at $7.95 \mathrm{ppm}$ were significantly broadened, which is not observed in free 4dimethylaminopyridine in $\mathrm{d}^{6}$-DMSO solution (See supplementary information), and which may be attributed to the ligand environment upon coordination to the $\left[\mathrm{Pd}_{3} \mathrm{Tr}_{2}\right]^{2}+$ unit. The protons in this position are shifted upfield in comparison with the free ligand $(8.08 \mathrm{ppm})$, but confirm the expected formulation. Such broadening is not observed in the ${ }^{1} \mathrm{H}$ NMR of the related complex $\left[\operatorname{Pd}(\mathrm{DMAP})_{4}\right]\left[\left(\mathrm{BF}_{4}\right)_{2}\right]$ in $\mathrm{CD}_{3} \mathrm{CN} .{ }^{22}{ }^{31} \mathrm{P}$ NMR showed no residual phosphorous containing species within the limits of detection. The ${ }^{19} \mathrm{~F}$ NMR showed a single peak at $-148.3 \mathrm{ppm}$ for the four equivalent fluorine atoms on the tetrafluoroborate ligands. Recrystallization from dichloromethane and diethyl ether gave single crystals suitable for X-ray diffraction studies.

The success synthesis of $\mathbf{3}$, suggested that reaction with other electron-donating ligands might be a useful direction. The ligand 4-dimethylaminobenzonitrile is structurally similar to DMAP but includes an extended pi-conjugated pathway through the nitrile group. Treatment of 
$[\mathrm{P}-n-\mathrm{Bu} 4]\left[\mathrm{Pd}_{3} \mathrm{Tr}_{2} \mathrm{Br}_{3}\right]$ with excess $\mathrm{AgSO}_{3} \mathrm{CF}_{3}$ and 4-(dimethylamino)benzonitrile in dichloromethane gave two distinct products, a colourless solid and a darker maroon-coloured precipitate 4 . The colourless solid was confirmed by multi-nuclear NMR to be $\left[\mathrm{PPh}_{4}\right]\left[\mathrm{SO}_{3} \mathrm{CF}_{3}\right]$. ${ }^{1} \mathrm{H}$ NMR studies on $\mathbf{4}$ indicate the presence of a single peak at $4.87 \mathrm{ppm}$ that may be attributed to the tropylium environment in the product. Two sets of signals were centered at 6.74 and 7.52 ppm, and can be attributed to the two unique hydrogen environments on the 4(dimethylamino)benzonitrile ring, however the peaks do not display the broadening observed in the ${ }^{1} \mathrm{H}$ NMR of 3 . The upfield shift that occurs in the ${ }^{1} \mathrm{H}$ NMR spectra of the tropylium peak of $\mathbf{3}$ in comparison with $\mathbf{4}$, is in agreement with the stronger coordination of pyridine over nitrile ligands that has been observed in other palladium complexes. ${ }^{23}$ Recrystallization from dichloromethane and diethyl ether gave single crystals of $\mathbf{4}$ suitable for X-ray diffraction studies. All of the above complexes were highly stable and gave clean NMR spectra even after several years of storage at room temperature.

\section{Spectroscopic characterization}

The ultra-violet and visible spectra $(800$ and $350 \mathrm{~nm})$ of compounds $\mathbf{1}-\mathbf{4}$ are dominated by a strong $\left(\varepsilon \sim 10^{4}\right)$ feature with a $\lambda_{\max }$ at approximately $401 \mathrm{~nm}$ with a shoulder near $450 \mathrm{~nm}$. This is consistent across the series and is independent of the ligand substituent. This is in contrast to the precursor series $[\mathrm{Y}]\left[\mathrm{Pd}_{3} \operatorname{Tr}_{2} \mathrm{X}_{3}\right]\left(\mathrm{Y}=\mathrm{NBu}_{4}, \mathrm{PBu}_{4}\right.$ or $\mathrm{PPh}_{4}, \mathrm{X}=\mathrm{Cl}, \mathrm{Br}$ or $\mathrm{I}$, $)$ where the ultra-violet and visible spectra is characterized by two major absorption peaks around 481 and $417 \mathrm{~nm}$. Comparison of the ultra-violet and visible absorption spectra for select complexes and the precursor $[\mathrm{PBu} 4]\left[\mathrm{Pd}_{3} \operatorname{Tr}_{2} \mathrm{Br}_{3}\right]$ is shown in Figure 1. The $417 \mathrm{~nm}$ absorption in $\left[\mathrm{PBu}_{4}\right]\left[\mathrm{Pd}_{3} \operatorname{Tr}_{2} \mathrm{Br}_{3}\right]$ is attributed to electronic absorption within the $\left[\mathrm{Pd}_{3} \mathrm{Tr}_{2}\right]^{2+}$ unit. In the newly reported series of 
complexes this peak undergoes a blue-shift upon replacement of the halide anions with the neutrally charged nitrogen-containing species. Comparison of the UV-visible spectrum of 1 a and 1b demonstrate the minimal influence of the counter anion on the absorption spectra.

In $\left[\mathrm{PPh}_{4}\right]\left[\mathrm{Pd}_{3} \operatorname{Tr}_{2} \mathrm{Cl}_{3}\right]$ the lower energy peak at $481 \mathrm{~nm}$ is attributed to electronic transfer between the $\left[\mathrm{Pd}_{3} \mathrm{Tr}_{2}\right]^{2+}$ unit and the negatively charged anionic species. ${ }^{7}$ Previous studies in which the electron-rich halides were replaced with neutral pnictogen ligands also led a shift of $\lambda_{\max }$ to higher energies. In the current series, this peak is also blue-shifted, consistent with the presence of the more electron-poor nitrogen-containing ligands. The ultra-violet and visible spectrum for $\mathbf{3}$ in a range of solvents of different polarity indicates no significant solvatochromic effects (Figure 2). None of the complexes in the present study demonstrated any evidence of fluorescent properties.

$<$ Figure 1 and Figure 2>

$X$-ray diffraction studies

The results of single crystal X-ray diffraction studies on compounds $\mathbf{1 a}, \mathbf{2}$ and $\mathbf{4}$ are summarized in Table 1 and selected bond lengths and angles are collected in Table 2.

$<$ Table 1 and Table 2>

$<$ Figure 3 $>$

$<$ Figure 4>

$<$ Figure 5 $>$

Previous work on the tripalladium ditropylium motif has revealed interesting structural characteristics, and the compounds described here are no exception. In compounds $\mathbf{1 b}, \mathbf{2}$ and $\mathbf{4}$ the triangular $\left[\mathrm{Pd}_{3} \mathrm{Tr}_{2}\right]^{2+}$ core is retained and the tropylium ring is planar in all the complexes 
characteristic of the expected aromaticity. In the $\left[\mathrm{Pd}_{3} \operatorname{Tr}_{2}\left(\mathrm{Py}_{3}\right]\left[\left(\mathrm{SO}_{3} \mathrm{CF}_{3}\right)_{2}\right]\right.$ complex $\mathbf{1 b}$ the tripalladium unit lays on a twofold rotation axis and thus the complete formula is twice the asymmetric unit. Interestingly the pyridine rings are oriented approximately planar to the plane of the palladium triangle with rotation away by $23.32^{\circ}$ for the two symmetry related pyridine ligands and $8.22^{\circ}$ for the remaining ligand. The Pd-Pd bond lengths are 2.7374(8) and 2.7857(6) $\AA$, shorter than in the previously studied pnictogen series. The Pd-N bond lengths are 2.202(3) and 2.208(4) $\AA$, slightly longer than in related structures of Pd(0). The internal Pd-Pd-Pd angles are all close to $60^{\circ}$ due to the homoleptic ligand substitution pattern.

Displacement of the pyridine ligands in 1a by recrystallization in acetonitrile gave the structure of $\left[\operatorname{Pd}_{3} \operatorname{Tr}_{2}(\mathrm{MeCN})_{3}\right]\left[\left(\mathrm{BF}_{4}\right)_{2}\right] 2$ which has previously been reported. ${ }^{24}$ Both structures of 2 show similar unit cell parameters, packing motif and similar $\mathrm{R}_{1}$ values. The Pd-Pd distances $(2.7692,2.7404$ and $2.7526 \AA)$ and angles $\left(59.507,59.945\right.$ and $\left.60.548^{\circ}\right)$ are also similar. The Pd-N distances are similar $(2.186,2.145$ and $2.155 \AA)$ and longer than those in related Pd(II) acetonitrile complexes $(1.956 \AA) .{ }^{25}$ The overall crystal packing in $\mathbf{2}$ shows evidence of aromatic stacking interactions that stabilize the overall structure.

The structure of $\mathbf{4}$ was also characterized by single crystal diffraction study. As shown in Figure 5, 4 possesses an internal $\left[\mathrm{Pd}_{3} \mathrm{Tr}_{2}\right]^{2+}$ unit mostly identical to that of the comparative structures. The Pd-Pd distances $(2.7678,2.7534$ and $2.7626 \AA)$ and angles $(60.05,59.72$ and $60.24^{\circ}$ ) in $\mathbf{4}$ are comparable to the pyridine (1b) and acetonitrile (2) derivatives (vide supra). In comparison however the Pd-N distances are significantly shorter (2.180, 2.149 and $2.150 \AA)$ than the pyridine derivative, and are comparable with those of the acetonitrile complex. This suggests that the relative type of ligand (e.g. nitrile, benzonitrile or pyridine) may not influence the structural parameters as much as the nature of the substituent on ligands of the same family. Also 
of interest is the relative orientation of the 4-(dimethylamino)benzonitrile ligands. In the structure of $\mathbf{1 b}$, two of the ligands are orientated close to planarity with the $\mathrm{Pd}_{3}$ unit, and this is also the case in $\mathbf{4}$. Unlike $\mathbf{1 b}$ however, $\mathbf{4}$ crystallizes in space group P-1 and thus the ligands are not related by symmetry. In all three 4-(dimethylamino)benzonitrile ligands the dimethylamino substituent is essentially coplanar with the aromatic ring. With respect to the $\mathrm{Pd}_{3}$ plane, ligand $\mathrm{A}$ (formed by atoms $\mathrm{N} 1$ to $\mathrm{C} 23$ ) is twisted by $13.33(3)^{\circ}$, ligand B (formed by atoms $\mathrm{N} 2$ to $\mathrm{C} 32$ ) twisted by $15.68(2)^{\circ}$ and ligand $\mathrm{C}$ (formed by atoms $\mathrm{N} 3$ to $\mathrm{C} 41$ ) is twisted by $83.79(15)^{\circ}$.

The crystal packing contains a mix of weak hydrogen bonding and aromatic stacking interactions. Figure 3 shows some edge-face and face-face $\pi \ldots \pi$ interactions. Close face-face stacking is found between adjacent cyclopentatrienyl ligands, as are edge-face interactions between the edge of the cyclopentatrienyl ligands and the face of adjacent 4(dimethylamino)benzonitrile ligands. Further overlapping face-face stacking between adjacent 4-(dimethylamino)benzonitrile ligands generates a three-dimensional framework supported entirely by aromatic stacking interactions (Figure 4). Such stacking interaction may be a useful method by which to stabilize large multi-dimensional arrays composed of $\left[\mathrm{Pd}_{3} \operatorname{Tr}_{2}\right]^{2+}$ derivatives.

During the synthesis of $\mathbf{3}$ small red crystals were isolated after repeated recrystallization attempts. The crystallographic data set was complete and of good resolution and redundancy. Structure solution and refinement initially suggested the previously unreported complex $[\mathrm{Pd}(\mathrm{DMAP}) 2][(\mathrm{BF})](\mathbf{5 a})$ (Figure 6). Although tetrakis substituted complexes of palladium with DMAP have been reported previously, ${ }^{26,27}$ no such comparable structure has been determined. A search of the Cambridge Structural Database showed no similar structures. None of the metal to nitrogen bond distances in the unit cell were significantly different $(2.100-2.118 \AA)$, indicating similar electronic environments around the metal centers in the asymmetric unit. Although $\operatorname{Pd}(\mathrm{I})-$ 
$\operatorname{Pd}(\mathrm{I})$ complexes have been reported previously, including $\left[\mathrm{Pd}_{2}(\mathrm{MeCN})_{6}\right]\left[\left(\mathrm{BF}_{4}\right)_{2}\right],{ }^{28}$ these have been stabilized by relatively strong palladium-palladium interactions. The presence of $\mathrm{AgBF}_{4}$ in the reaction supports an alternate hypothesis that the structure may potentially be $\left[\operatorname{Ag}(\mathrm{DMAP})_{2}\right]\left[\left(\mathrm{BF}_{2}\right)\right](\mathbf{5 b})$ the synthesis of which was recently reported..$^{29}$ The bond lengths and angles for $\mathbf{5 b}$ are very similar to that of the related complex $\left[\mathrm{Ag}(\mathrm{DMAP})_{2}\right]\left(\mathrm{NO}_{3}\right) \cdot 2 \mathrm{H}_{2} \mathrm{O} .{ }^{30}$ Within the unit cell the $\operatorname{Ag}(2)-\operatorname{Ag}(2)$ bond length of 3.0347(5) $\AA$ is very close to that previously reported for $\left[\mathrm{Ag}(\mathrm{DMAP})_{2}\right](4-$ bromophenylacetate $) \cdot \mathrm{H}_{2} \mathrm{O}(3.0395(12) \AA) .{ }^{31}$ In the current structure the complex has distorted linear coordination geometry around the metal ion, with two molecules in the asymmetric unit. The closest metal-metal contact is $3.035 \AA$ suggestive of weak interaction and which causes distortion of the metal atom out of the plane defined by the ligands.

Refinement of the metal centers as palladium gives $\mathrm{R}_{1}$ of $3.27 \%$ and $\mathrm{wR}_{2}$ of $6.65 \%$. Subsequent refinement of the occupancies gives occupancies for $\operatorname{Pd}(1)$ of 0.98845 and $\operatorname{Pd}(2)$ to 0.98337. Changing the metal element to silver then refines $\operatorname{Ag}(1)$ with an occupancy of 0.9633 while $\operatorname{Ag}(2)$ is $0.9581\left(\mathrm{R}_{1}=3.30 \%, \mathrm{wR}_{2}=6.90 \%\right)$ However, if the $\mathrm{Ag}$ occupancies are set to 1 this produces $\mathrm{R}_{1}$ of $3.42 \%$ and $\mathrm{wR}_{2}=7.55 \%$. Disorder modelling of the tetrafluoroborate counterions gives a decrease in the $\mathrm{R}$ values for both metal atoms, but does not significantly alter the relative values. This suggests that from a purely crystallographic point of view the metals are palladium and not silver. Comparison with related structures and the presence of $\mathrm{AgBF}_{4}$ in the reaction mixture nevertheless leads us to consider the central metal atom to be silver. The ambiguity of atomic centers with similar atomic masses is a well known issue in crystallography, ${ }^{32}$ and further studies are underway to determine unambiguously the nature of the metal atoms.

$<$ Figure 6> 


\section{Conclusions}

This series of complexes demonstrates a range of nitrogen-based ligands bound to the tripalladium ditropylium complex $\left[\mathrm{Pd}_{3} \mathrm{Tr}_{2}\right]^{2+}$. NMR and single-crystal diffraction studies have helped in understanding the influence of the ligand substituent on the structure-property relationships. New ligand systems including substituted cycloheptatrienes and multidentate nitrogen systems will extend the variety of unusual metal coordination motifs. ${ }^{33}$ The coordination of the nitrogen lone pair in an "end-on" configuration suggests that the complex may have significant potential to form extended multi-dimensional systems as well as possessing catalytic activity in carbon-carbon bond forming reactions. In order to gain further insight into potential molecular configurations, studies involving multidentate ligands including cyanopyridine and pyrazine are currently underway. 


\section{General Methods}

All experiments were performed under an Ar atmosphere using standard Schlenk techniques. ${ }^{1} \mathrm{H},{ }^{13} \mathrm{C}\left\{{ }^{1} \mathrm{H}\right\},{ }^{31} \mathrm{P}\left\{{ }^{1} \mathrm{H}\right\}$, and ${ }^{19} \mathrm{~F}$ NMR spectra were recorded on a $400 \mathrm{MHz}$ (Varian Mercury) instrument, and the chemical shifts were referenced to the residual resonances of the deuterated solvents. Electronic spectra were recorded using a Bruker Cary50 UV-VIS spectrophotometer. Fluorescence spectra were recorded using a Agilent spectrophotometer. Elemental analyses were performed by Robertson Microlit Laboratories Inc. of Madison, New Jersey, and the School of Oceanography at the University of Rhode Island. $\mathrm{CH}_{2} \mathrm{Cl}_{2}, \mathrm{CH}_{3} \mathrm{Cl}, \mathrm{CH}_{3} \mathrm{CN}$, hexanes, pyridine and $\mathrm{Et}_{2} \mathrm{O}$ were purified according to standard procedures. [P- $\left.n-\mathrm{Bu}_{4}\right]\left[\mathrm{Pd}_{3} \mathrm{Tr}_{2} \mathrm{Br}_{3}\right]$ was prepared according to the method of Babbini et al. ${ }^{20}$ The chemicals 4-dimethylaminopyridine (DMAP), 4dimethylaminobenzonitrile (DMAB), $\mathrm{AgBF}_{4}$, and $\mathrm{AgSO}_{3} \mathrm{CF}_{3}$ were purchased from the Sigma Aldrich Corporation and used without further purification. Deuterated solvents were purchased from Cambridge Isotope Laboratories. 
Synthesis of $\left[\mathbf{P d}_{3} \operatorname{Tr}_{2}(\mathbf{P y})_{3}\right]\left(\mathbf{B F}_{4}\right)_{2} \mathbf{( 1 a )}$ To a solution of $\left[\mathrm{P}-\mathrm{n}-\mathrm{Bu}_{4}\right]\left[\mathrm{Pd}_{3} \operatorname{Tr}_{2} \mathrm{Br}_{3}\right](106.2 \mathrm{mg}, 0.106$ $\mathrm{mmol})$ in pyridine $(15 \mathrm{~mL}), \mathrm{AgBF}_{4}(127.1 \mathrm{mg}, 0.653 \mathrm{mmol})$ was added and the solution was stirred for $1 \mathrm{~h}$. The solution was filtered leaving a dark burgundy colored precipitate and a clear filtrate. The precipitate was collected by filtration and washed with small quantities of diethyl ether $(2 \times 20 \mathrm{~mL})$ and then dried in vacuo. The product was then crystallized via vapor diffusion of diethyl ether into $\mathrm{CH}_{2} \mathrm{Cl}_{2}$. Yield: $51.3 \mathrm{mg}$ (53\%). Anal. Calcd. For $\mathrm{C}_{29} \mathrm{H}_{29} \mathrm{~B}_{2} \mathrm{~F}_{8} \mathrm{~N}_{3} \mathrm{Pd}_{3}$ : C, 38.17; H, 3.20; N, 4.61. Found: C, 38.36; H, 3.61; N, 4.88. ${ }^{1} \mathrm{H}$ NMR (400 MHz, d $-\mathrm{DMSO}, 25$ $\left.{ }^{\circ} \mathrm{C}\right): \delta 4.81\left(\mathrm{~s}, 14 \mathrm{H}, \mathrm{H}_{1}\right), 7.38-7.45\left(\mathrm{~m}, 6 \mathrm{H}, \mathrm{H}_{3}\right), 7.79-7.84\left(\mathrm{~m}, 3 \mathrm{H}, \mathrm{H}_{4}\right), 8.51-8.54(\mathrm{~m}, 3 \mathrm{H}$, $\left.\mathrm{H}_{2}\right) .{ }^{19} \mathrm{~F}\left(376.2 \mathrm{MHz}, \mathrm{d}^{6}-\mathrm{DMSO}, 25{ }^{\circ} \mathrm{C}\right): \delta-148.3\left(\mathrm{~s}, \mathrm{~F}_{1}\right)$. UV-Visible $\left[\mathrm{CH}_{2} \mathrm{Cl}_{2} \lambda_{\max }(\mathrm{nm}) 400.9\right.$ $\left.\left(6.1 \times 10^{3}\right)\right]$

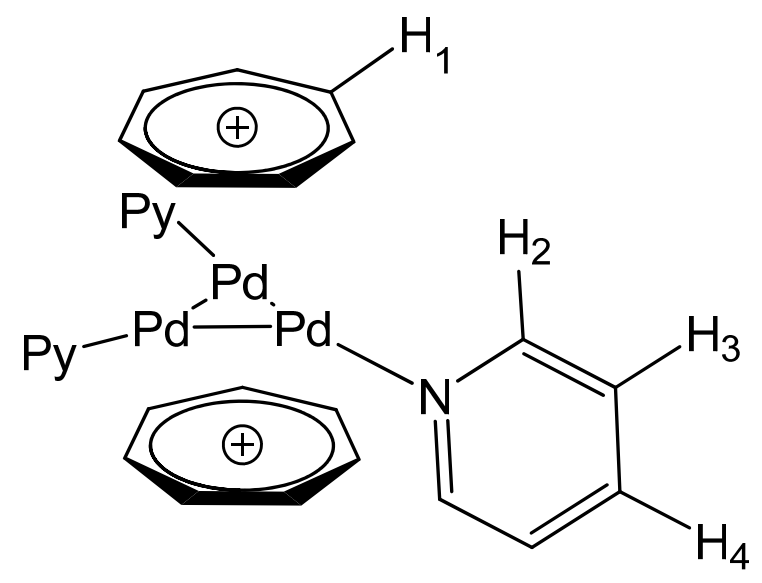<smiles>F[B-](F)(F)F</smiles> 
Synthesis of $\left.\left[\mathbf{P d}_{3} \operatorname{Tr}_{2}(\mathbf{P y})_{3}\right]\left(\mathbf{S O}_{3} \mathbf{C F}_{3}\right)_{2} \mathbf{( 1 b}\right)$ To a solution of $\left[\mathrm{PPh}_{4}\right]\left[\mathrm{Pd}_{3} \operatorname{Tr}_{2} \mathrm{Br}_{3}\right](105.4 \mathrm{mg}$, $0.0975 \mathrm{mmol})$ in dichloromethane $(30 \mathrm{~mL})$ and pyridine $(0.3 \mathrm{~mL}), \mathrm{AgSO}_{3} \mathrm{CF}_{3}(245.3 \mathrm{mg}, 0.955$ mmol) was added and the solution was stirred for $1 \mathrm{~h}$. The solution was filtered leaving a dark burgundy colored precipitate and a clear filtrate. The precipitate was collected by filtration and washed with small quantities of diethyl ether $(2 \times 25 \mathrm{~mL})$ and then dried in vacuo. The product was then crystallized via vapor diffusion of diethyl ether into $\mathrm{CH}_{2} \mathrm{Cl}_{2}$. Yield: $78.9 \mathrm{mg}(78 \%$ ). Anal. Calcd. For $\mathrm{C}_{31} \mathrm{H}_{29} \mathrm{~F}_{6} \mathrm{~N}_{3} \mathrm{O}_{6} \mathrm{Pd}_{3} \mathrm{~S}_{2}: \mathrm{C}, 35.91 ; \mathrm{H}, 2.82 ; \mathrm{N}, 4.05$. Found: $\mathrm{C}, 35.76 ; \mathrm{H}, 3.93 ; \mathrm{N}$, 4.40. ${ }^{1} \mathrm{H}$ NMR $\left(400 \mathrm{MHz}, \mathrm{d}^{6}-\mathrm{DMSO}, 25^{\circ} \mathrm{C}\right): \delta 4.83\left(\mathrm{~s}, 14 \mathrm{H}, \mathrm{H}_{1}\right), 7.35-7.45\left(\mathrm{~m}, 6 \mathrm{H}, \mathrm{H}_{3}\right), 7.79-$ $7.85(\mathrm{~m}, 3 \mathrm{H}, \mathrm{H} 4), 8.51-8.54\left(\mathrm{~m}, 6 \mathrm{H}, \mathrm{H}_{2}\right),{ }^{19} \mathrm{~F}\left(376.2 \mathrm{MHz}, \mathrm{d}^{6}-\mathrm{DMSO}, 25^{\circ} \mathrm{C}\right): \delta-77.7\left(\mathrm{~s}, \mathrm{~F}_{1}\right)$. UV-Visible $\left[\mathrm{CH}_{2} \mathrm{Cl}_{2} \lambda_{\max }(\mathrm{nm}) 405.0\left(4.0 \times 10^{3}\right)\right]$.

<smiles>O=S(=O)([O-])C(F)(F)F</smiles> 
Synthesis of $\left[\mathbf{P d}_{3} \operatorname{Tr}_{2}(\mathbf{D M A P})_{3}\right]\left(\mathbf{B F}_{4}\right)_{2} \mathbf{( 3 )}$ To a solution of [P-n-Bu4] $\left.\mathrm{Pd}_{3} \operatorname{Tr}_{2} \mathrm{Br}_{3}\right](100.4 \mathrm{mg}, 0.10$ mmol) and DMAP (371.4 mg, $3.04 \mathrm{mmol})$ in $\mathrm{CH}_{2} \mathrm{Cl}_{2}(30 \mathrm{~mL}), \mathrm{AgBF}_{4}(194.4 \mathrm{mg}, 0.61 \mathrm{mmol})$ was added at room temperature with stirring to give a reddish-brown solution and a silver colored precipitate. The solution was filtered and diethyl ether $(100 \mathrm{~mL})$ was added, yielding a dark red precipitate. The solution was filtered and the precipitate was washed with diethyl ether $(2 \times 25 \mathrm{~mL})$ and dried in vacuo. Repeated attempts to crystallize $\mathbf{3}$ gave crystals of $\mathbf{5 b}$. Yield: 47.5 mg (65 \%). Anal. Calcd. For $\mathrm{C}_{35} \mathrm{H}_{44} \mathrm{~B}_{2} \mathrm{~F}_{8} \mathrm{~N}_{6} \mathrm{Pd}_{3}$ : C, 40.36; H, 4.26; N, 8.07. Found: $\mathrm{C}$, 40.90; H, 4.84; N, 7.92. ${ }^{1} \mathrm{H}$ NMR (400 MHz, $\left.\mathrm{d}^{6}-\mathrm{DMSO}, 25{ }^{\circ} \mathrm{C}\right): \delta 3.00(\mathrm{~s}, 18 \mathrm{H}, \mathrm{H} 5), 4.66(\mathrm{~s}$, 14H, $\left.\mathrm{H}_{1}\right), 6.68\left(\mathrm{~d}, 6 \mathrm{H}, \mathrm{H}_{3}\right), 7.95$ (bs, 6H, $\left.\mathrm{H}_{2}\right) .{ }^{19} \mathrm{~F}\left(376.2 \mathrm{MHz}, \mathrm{d}^{6}-\mathrm{DMSO}, 25{ }^{\circ} \mathrm{C}\right): \delta-148.3(\mathrm{~s}$, F1). UV-Visible $\left[\mathrm{CH}_{2} \mathrm{Cl}_{2} \lambda_{\max }(\mathrm{nm}) 401.0\left(13.7 \times 10^{3}\right)\right]$.

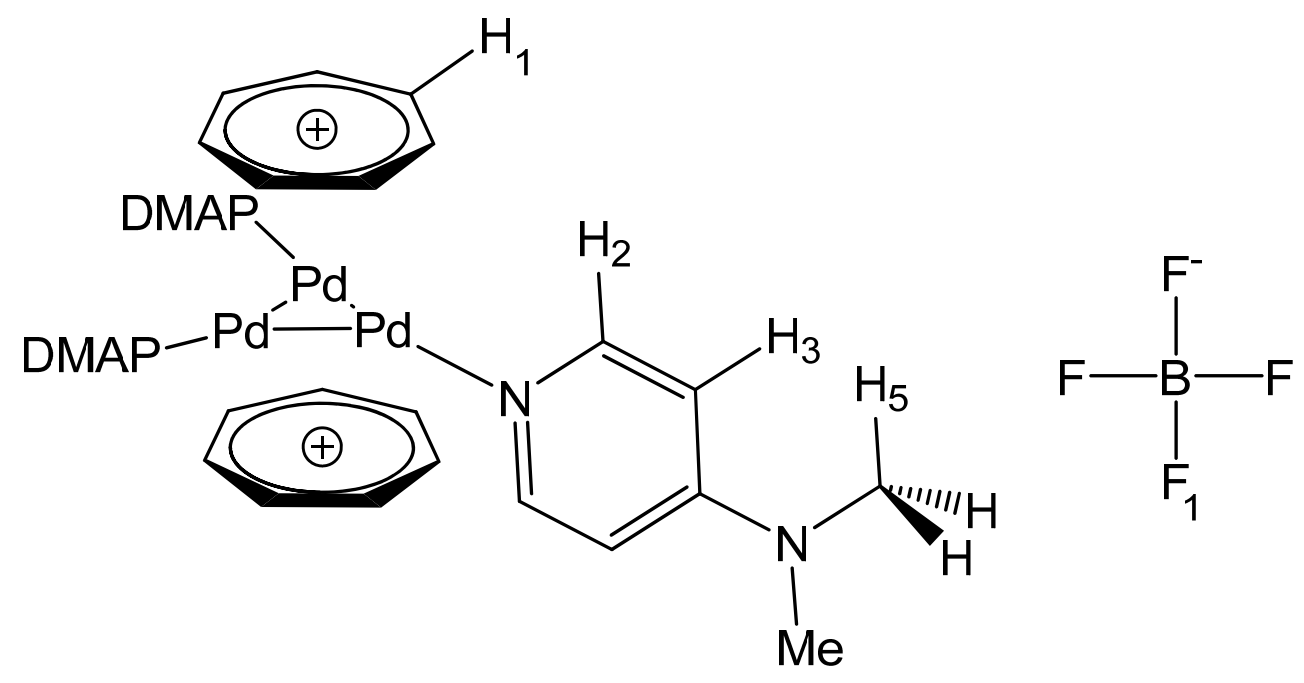

Alternate Synthesis of $\left[\mathbf{P d}_{3} \operatorname{Tr}_{2}(\mathbf{D M A P})_{3}\right]\left(\mathbf{B F}_{4}\right)_{2}(\mathbf{3})$ To a solution of $\left[\mathrm{Pd}_{2}(4-\mathrm{MeO}-\mathrm{dba})_{3}\right] \cdot \mathrm{CHCl}_{3}$ (100.2 mg, $0.088 \mathrm{mmol})$ and DMAP $(20.3 \mathrm{mg}, 0.166 \mathrm{mmol})$ in $\mathrm{CH}_{2} \mathrm{Cl}_{2}(30 \mathrm{~mL}), \mathrm{Tr} \cdot \mathrm{BF}_{4}(22.1$ $\mathrm{mg}, 0.124 \mathrm{mmol})$ was added at room temperature with stirring. The purple colour of the $\left[\mathrm{Pd}_{2}(4-\right.$ $\left.\mathrm{MeO}-\mathrm{dba})_{3}\right] \cdot \mathrm{CHCl}_{3}$ changed rapidly to give a reddish-brown solution containing a dark 
precipitate. After 18 hours the solution was filtered and the solid precipitate was washed with tert-butyl methyl ether $(2 \times 20 \mathrm{~mL})$ and dried in vacuo. Yield: $72.3 \mathrm{mg}(56 \%)$. Characterization data for the collected brown solid was identical to that of $\mathbf{3}$ reported above. 
Synthesis of $\left[\mathbf{P d}_{3} \operatorname{Tr}_{2}(\mathbf{D M A B})_{3}\right]\left(\mathbf{S O}_{3} \mathbf{C F}_{3}\right)_{2}$ (4) To a solution of $\left[\mathrm{PPh}_{4}\right]\left[\mathrm{Pd}_{3} \operatorname{Tr}_{2} \mathrm{Br}_{3}\right](72.0 \mathrm{mg}$, $0.0066 \mathrm{mmol})$ and DMAB $(76.2 \mathrm{mg}, 0.521 \mathrm{mmol})$ in $\mathrm{CH}_{2} \mathrm{Cl}_{2}(50 \mathrm{~mL}), \mathrm{AgSO}_{3} \mathrm{CF}_{3}(184.0 \mathrm{mg}$, $0.716 \mathrm{mmol}$ ) was added and the solution was stirred for $16 \mathrm{~h}$. The filtrate was reduced in volume to $\sim 30 \mathrm{~mL}$ and hexanes $(100 \mathrm{~mL})$ were added, yielding a dark red precipitate. The solution was filtered and the red precipitate was washed with hexanes $(2 \times 25 \mathrm{~mL})$ and dried in vacuo. The product was then crystallized via vapor diffusion of diethyl ether into $\mathrm{CH}_{2} \mathrm{Cl}_{2}$. Yield: $59.4 \mathrm{mg}$ (72 \%). Anal. Calcd. For $\mathrm{C}_{43} \mathrm{H}_{44} \mathrm{~F}_{6} \mathrm{~N}_{6} \mathrm{O}_{6} \mathrm{Pd}_{3} \mathrm{~S}_{2}$ : C, 41.71; H, 3.58; N, 6.79. Found: C, 40.71; H, 3.42; N, 6.82. ${ }^{1} \mathrm{H}$ NMR (400 MHz, d $\left.\mathrm{d}^{6}-\mathrm{DMSO}, 25{ }^{\circ} \mathrm{C}\right): \delta 2.98\left(\mathrm{~s}, 18 \mathrm{H}, \mathrm{H}\right.$ ), $4.87\left(\mathrm{~s}, 14 \mathrm{H}, \mathrm{H}_{1}\right)$, $6.74\left(\mathrm{~d}, 6 \mathrm{H}, \mathrm{H}_{3}, \mathrm{~J}_{\mathrm{HH}}=9 \mathrm{~Hz}\right), 7.52\left(\mathrm{~d}, 6 \mathrm{H}, \mathrm{H}_{2}, \mathrm{~J}_{\mathrm{HH}}=9 \mathrm{~Hz}\right) .{ }^{19} \mathrm{~F}\left(376.2 \mathrm{MHz}, \mathrm{d}^{6}-\mathrm{DMSO}, 25{ }^{\circ} \mathrm{C}\right): \delta$ $-77.8\left(\mathrm{~s}, \mathrm{~F}_{1}\right) . \mathrm{UV}$-Visible $\left[\mathrm{CH}_{2} \mathrm{Cl}_{2} \lambda_{\max }(\mathrm{nm}) 400.1\left(7.9 \times 10^{3}\right)\right]$.

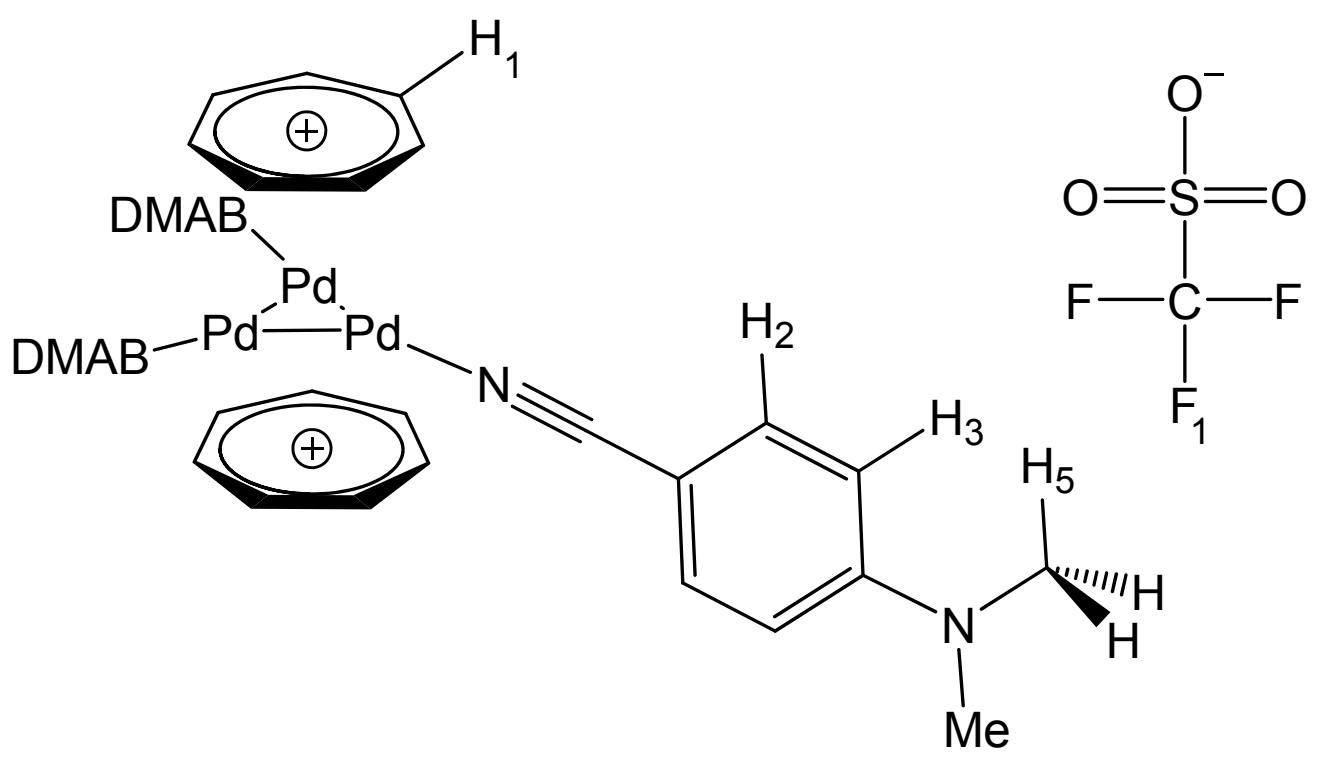




\section{Single crystal X-ray diffraction}

Single crystal X-ray diffraction data were collected on either Nonius KappaCCD (1) or Bruker SMART $\left(\mathbf{2}, 4\right.$ \& 5b) diffractometers. The EvalCCD ${ }^{34}$ and SMART/SAINT ${ }^{35}$ software packages were used for data processing; structures were solved with SIR92 ${ }^{36}$ or SHELXS ${ }^{37}$ and refined using SHELXL ${ }^{37}$. In all cases hydrogen atoms were placed geometrically, with $\mathrm{C}-\mathrm{H}$ distances in the range $0.95-0.99 \AA$ (according to hybridization) and refined with $\mathrm{U}_{\text {iso }}(\mathrm{H})=1.2 \mathrm{U}_{\text {eq }}(\mathrm{C})$ $\left(\mathrm{U}_{\mathrm{iso}}(\mathrm{H})=1.5 \mathrm{U}\right.$ eq $(\mathrm{C})$ for methyl hydrogen atoms $)$.

In the structure of $\mathbf{2}$ one of the tetrafluoroborate counterions (the atoms B1 to F4) was refined using a whole-molecule, two-part disorder model with a refined major:minor occupancy ratio of 66:44 \%. Restraints were used on this disordered counterion to keep the displacement parameters and bond distances similar to the ordered counterion. 


\section{Acknowledgments}

We wish to thank Northern Arizona University and the College of Engineering, Forestry and Natural Sciences for start up funding. We thank the Research Corporation for Science Advancement for their support though the Cottrell College Science Award (ID 10600). We also thank and the American Chemical Society Petroleum Research Fund (ACS-PRF Grant \# 51546UR3). Crystallographic data for $\mathbf{1 b}$ was collected by Professor Bill Clegg and Dr. Ross W. Harrington of Newcastle University. The X-ray diffractometer for 2, 4 and $\mathbf{5}$ was purchased with funds from NSF grant CHE-9610374. We wish to extend our thanks to the 2013 American Crystallographic Association Summer Course in Chemical Crystallography and to Prof. Alan Balch for insightful discussions. S.K.H personally wishes to thank the many undergraduate students who worked on this challenging project over many years.

\section{Supporting information available.}

CCDC 1428954-1428956 and 1429150 contains the supplementary crystallographic data for 1b, 2, 4 and 5b. These data can be obtained free of charge via https://summary.ccdc.cam.ac.uk/structure-summary-form, or from the Cambridge Crystallographic Data Centre, 12 Union Road, Cambridge CB2 1EZ, UK; fax: (+44) 1223-336033; or e-mail: deposit@ccdc.cam.ac.uk. The supplementary data for the above complexes and $\mathbf{5}$ can also be found, in the online version, at http://dx.doi.org/ 


\section{Scheme, Figure and Table Captions}

Scheme 1: $\quad$ Synthesis pathways for complexes 1 - 4 .

Figure 1. UV-visible spectra of complexes $\mathbf{1 a}, \mathbf{1 b}, \mathbf{3}, \mathbf{4}$ and $\left[\mathrm{PBu}_{4}\right]\left[\mathrm{Pd}_{3} \operatorname{Tr}_{2} \mathrm{Br}_{3}\right]$ in dichloromethane. Absorption normalized to 1.0 at $400 \mathrm{~nm}$ for comparison purposes.

Figure 2. UV-visible spectra of $\mathbf{3}$ in dichloromethane, methanol and acetonitrile. Absorption normalized to 1.0 at $400 \mathrm{~nm}$ for comparison purposes.

Figure 3. Plot of $\mathbf{1 b}$ at $50 \%$ probability level with hydrogen atoms and counterions omitted.

Figure $4 . \quad$ Plot of $\mathbf{2}$ at $30 \%$ probability level with anions omitted.

Figure 5. Plot of $\mathbf{4}$ at 50\% probability level with solvent molecule and counterions omitted.

Figure 6. Plot of $\mathbf{5}$ at $50 \%$ probability level with hydrogen atoms omitted.

Table 1. Crystal data for compounds $\mathbf{1 b}, \mathbf{2}, \mathbf{4}$ and $\mathbf{5}$.

Table 2. $\quad$ Selected bond lengths $(\AA)$ and angles $\left(^{\circ}\right)$ for compounds $\mathbf{1 b}, \mathbf{2}, \mathbf{4}$ and $\mathbf{5}$. 


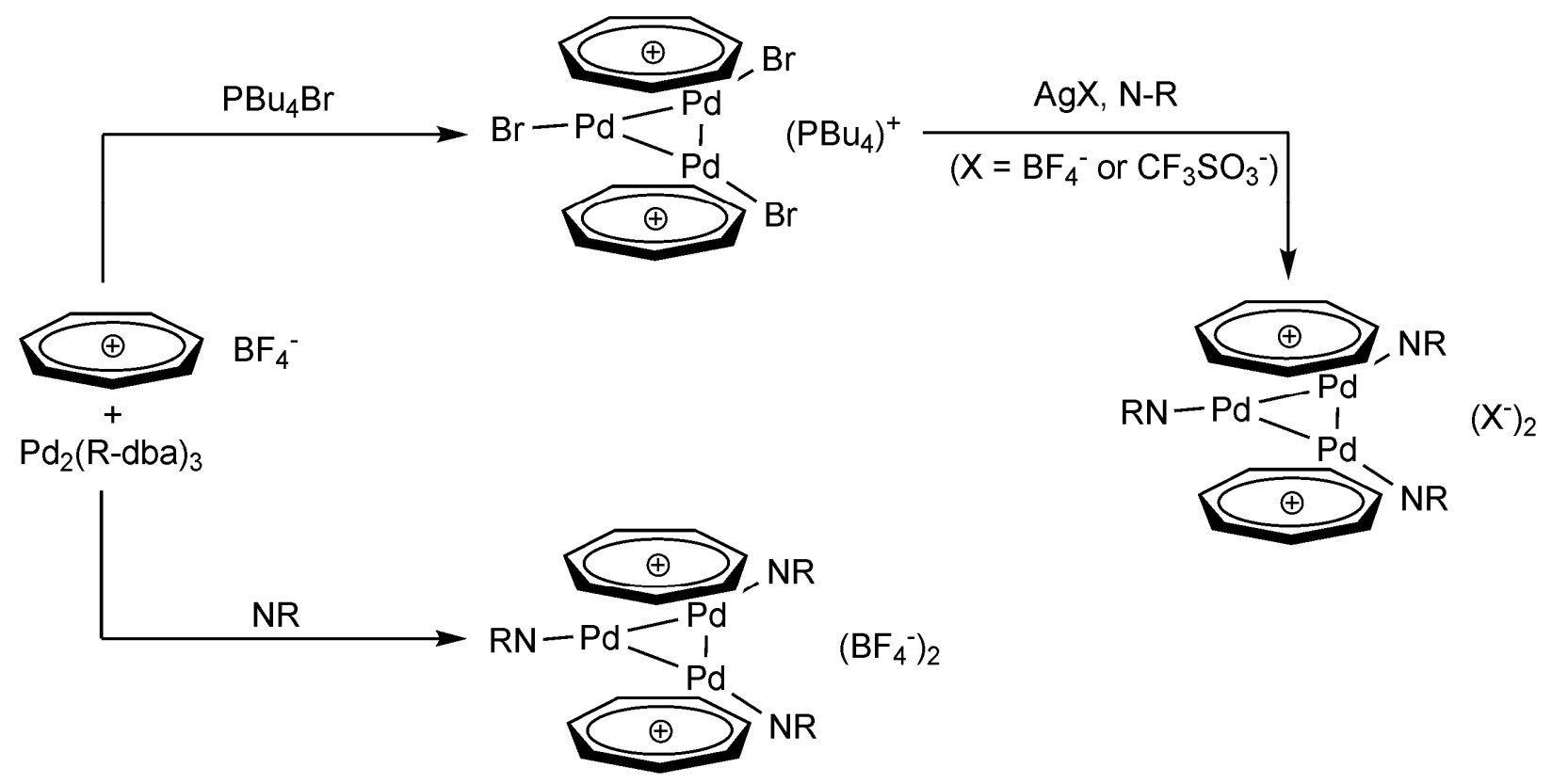

Scheme 1: Synthesis pathways for complexes 1 - 4. 


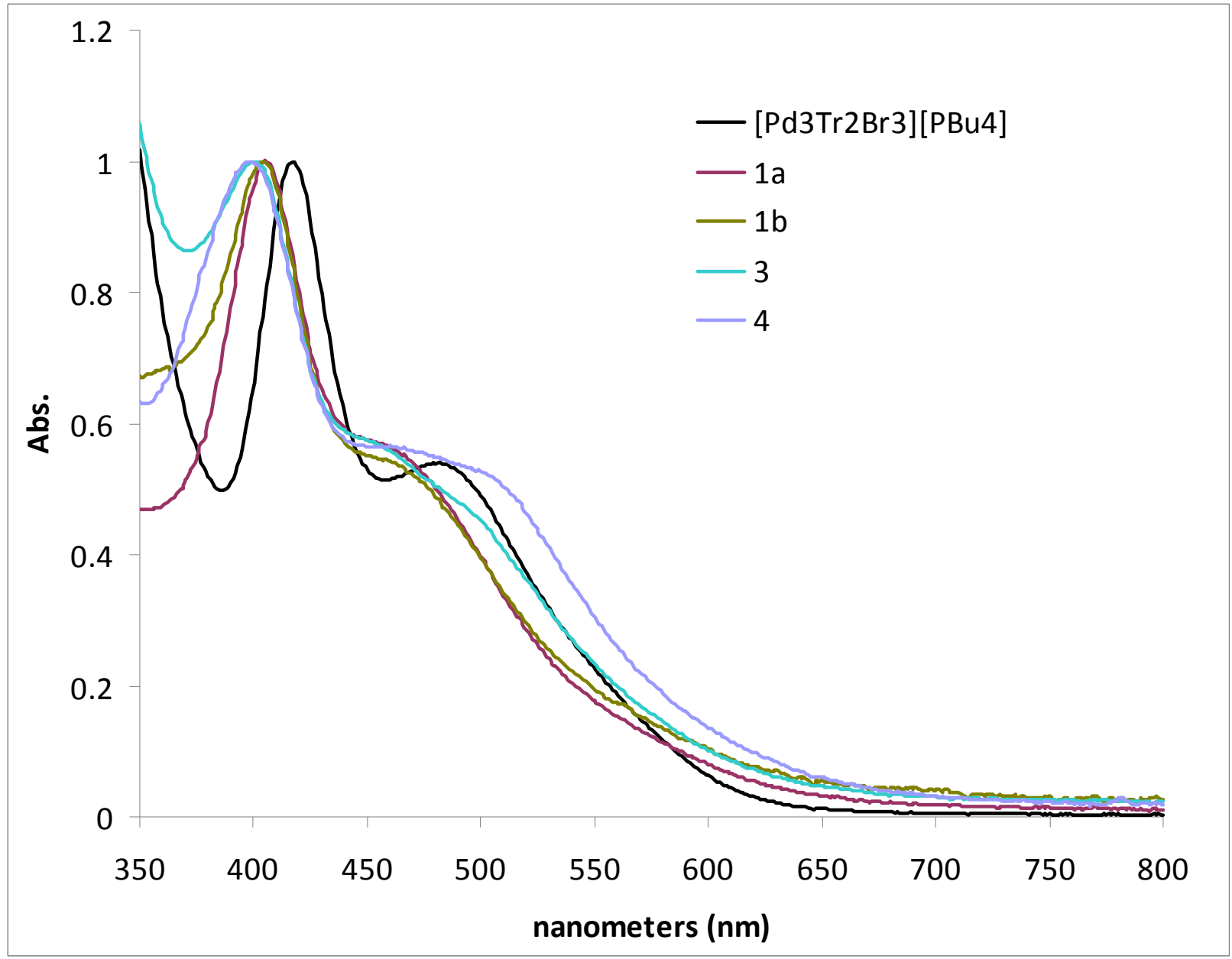

Figure 1. UV-visible spectra of complexes $\mathbf{1 a}, \mathbf{1 b}, \mathbf{3}, \mathbf{4}$ and $\left[\mathrm{PBu}_{4}\right]\left[\mathrm{Pd}_{3} \operatorname{Tr}_{2} \mathrm{Br}_{3}\right]$ in dichloromethane. Absorption normalized to 1.0 at $400 \mathrm{~nm}$ for comparison purposes. 




Figure 2. UV-visible spectra of $\mathbf{3}$ in dichloromethane, methanol and acetonitrile. Absorption normalized to 1.0 at $400 \mathrm{~nm}$ for comparison purposes. 


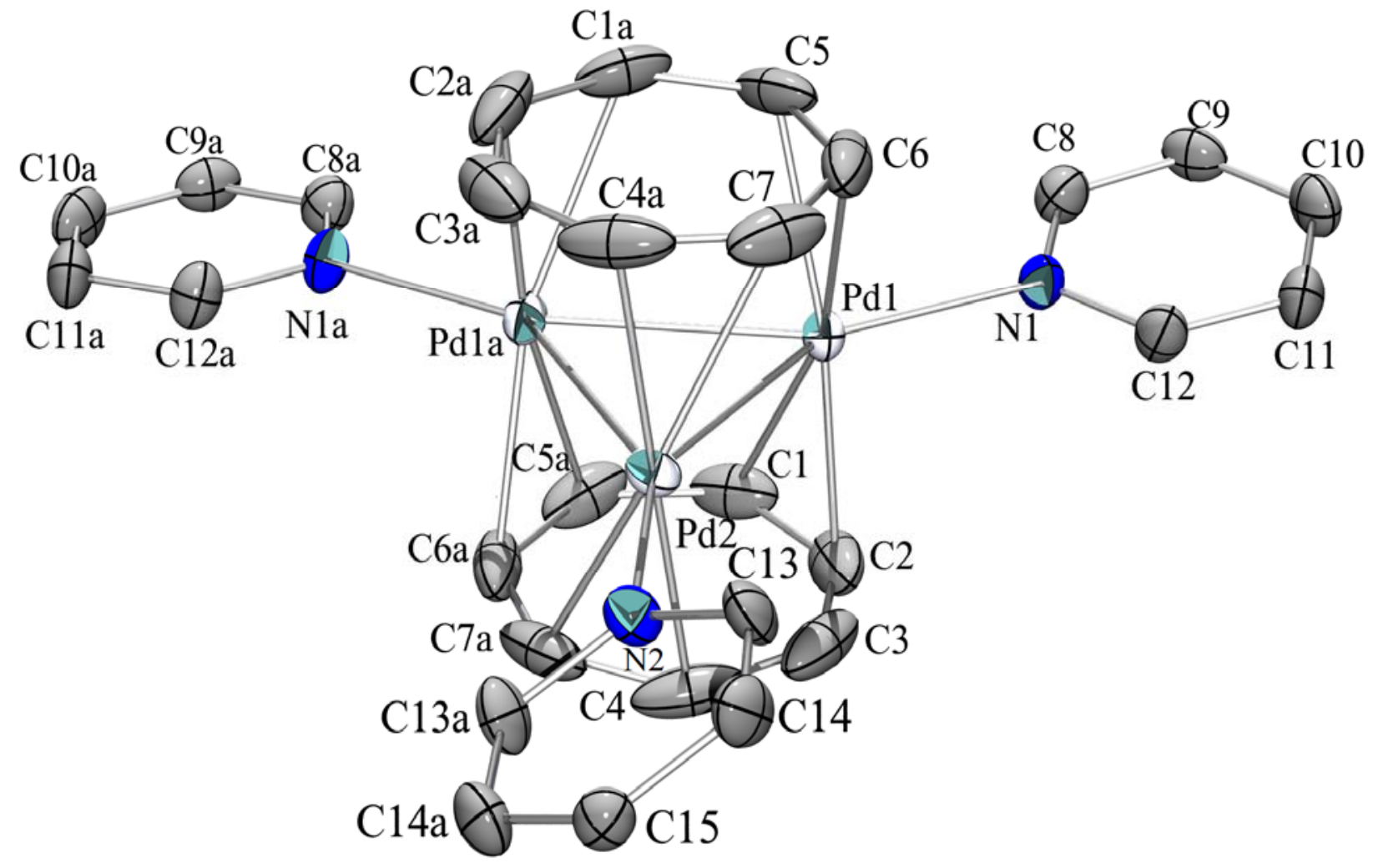

Figure 3. Plot of $\mathbf{1 b}$ at 50\% probability level with hydrogen atoms and counterions omitted. 


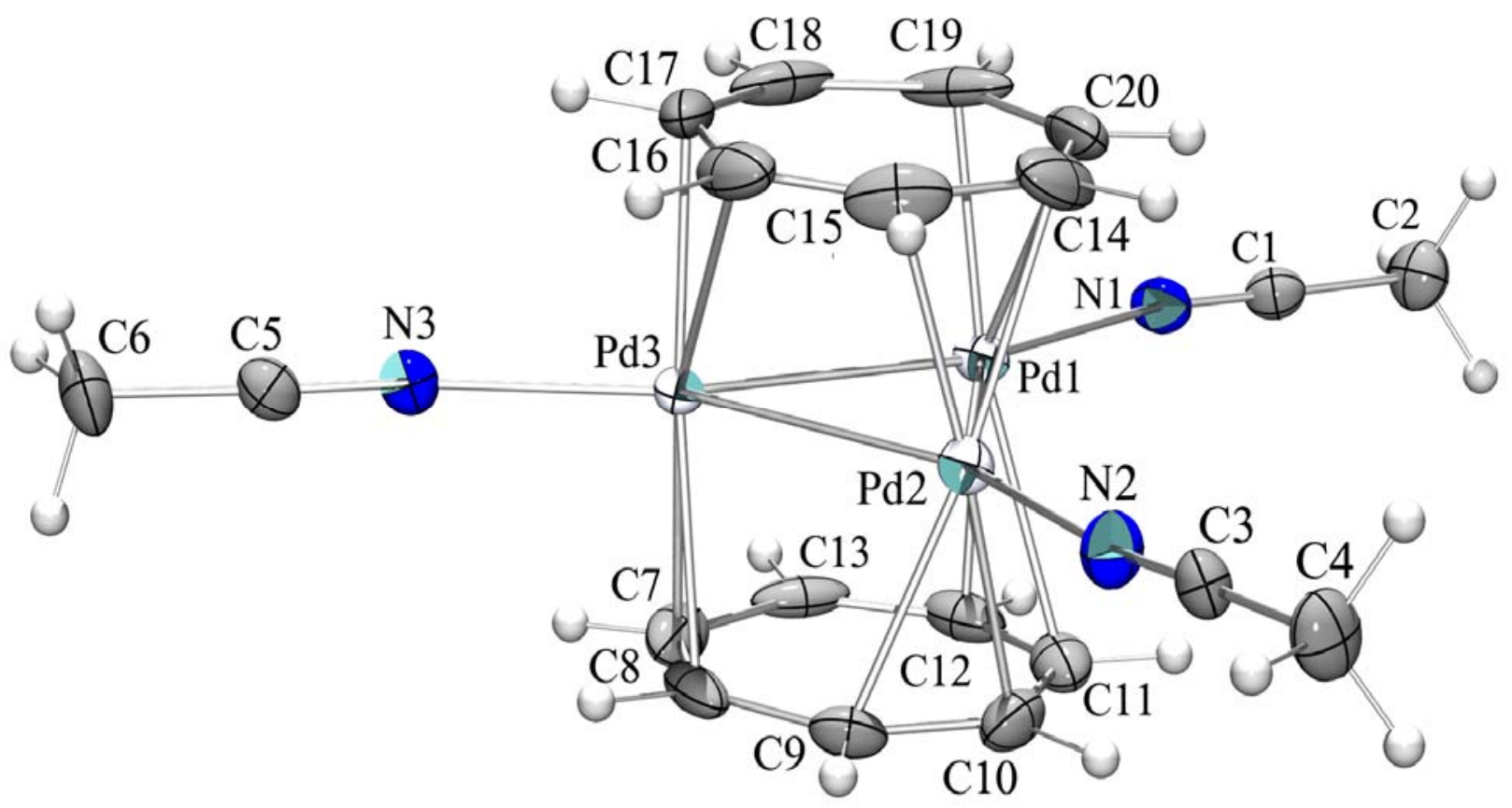

Figure 4. Plot of $\mathbf{2}$ at $30 \%$ probability level with anions omitted. 




Figure 5. Plot of $\mathbf{4}$ at 50\% probability level with solvent molecule and counterions omitted. 




Figure 6. Plot of 5a at 50\% probability level with hydrogen atoms and counterions omitted. 
Table 1. Crystal data for compounds $\mathbf{1 b}, \mathbf{2}, \mathbf{4}$ and $\mathbf{5 a}{ }^{a}$

\begin{tabular}{|c|c|c|c|c|}
\hline & $1 \mathrm{~b}$ & 2 & 4 & $5 \mathbf{a}$ \\
\hline $\begin{array}{l}\text { Moiety } \\
\text { Formula }\end{array}$ & $\begin{array}{c}\mathrm{C}_{29} 9 \mathrm{H}_{29} \mathrm{~N}_{3} \mathrm{Pdd}_{3}{ }_{3+} \\
2 \mathrm{CF}_{3} \mathrm{O}_{3} \mathrm{~S}_{2}-\end{array}$ & $\begin{array}{c}\mathrm{C}_{20} \mathrm{H}_{23} \mathrm{~N}_{3} \mathrm{Pdd}_{3}{ }^{2+} . \\
2 \mathrm{BF}_{4}^{-}\end{array}$ & $\begin{array}{c}\mathrm{C}_{41} \mathrm{H}_{44} \mathrm{H}_{6} \mathrm{Pd}_{\mathrm{Pd}^{2+}} \\
2 \mathrm{CF}_{3} \mathrm{O}_{3} \mathrm{~S}_{2}^{-} \\
\mathrm{CH}_{2} \mathrm{Cl}_{2}\end{array}$ & $\begin{array}{c}\mathrm{C}_{144} \mathrm{H}_{20} \mathrm{Ag}^{+} \cdot \\
2 \mathrm{BF}_{4}^{-}\end{array}$ \\
\hline $\begin{array}{c}\text { Total } \\
\text { Formula }\end{array}$ & $\begin{array}{c}\mathrm{C}_{31} \mathrm{H}_{29} \mathrm{~F}_{6} \mathrm{~N}_{3} \mathrm{O}_{6} \mathrm{P} \\
\mathrm{d}_{3} \mathrm{~S}_{2}\end{array}$ & $\begin{array}{c}\mathrm{C}_{20} \mathrm{H}_{23} \mathrm{~B}_{2} \mathrm{~F}_{8} \mathrm{~N}_{3} \mathrm{P} \\
\mathrm{d}_{3}\end{array}$ & $\begin{array}{c}\mathrm{C}_{44} \mathrm{H}_{46} \mathrm{Cl}_{2} \mathrm{~F}_{6} \mathrm{~N}_{6} \\
\mathrm{O}_{6} \mathrm{Pd}_{3} \mathrm{~S}_{2}\end{array}$ & $\mathrm{C}_{14} \mathrm{H}_{20} \mathrm{AgBF}_{4} \mathrm{~N}_{4}$ \\
\hline $\begin{array}{c}\text { Formula } \\
\text { weight }\end{array}$ & 1036.89 & 798.23 & 1323.09 & 439.02 \\
\hline $\begin{array}{l}\text { Radiation } \\
\text { type }\end{array}$ & $\begin{array}{c}\text { MoKa, } \\
0.71073 \AA\end{array}$ & $\begin{array}{c}\text { MoKa, } \\
0.71073 \AA\end{array}$ & $\begin{array}{c}\text { MoKa, } \\
0.71073 \AA\end{array}$ & $\begin{array}{c}\text { MoKa, } \\
0.71073 \AA\end{array}$ \\
\hline Space group & $\begin{array}{l}\text { Monoclinic, } \\
C 2 / c\end{array}$ & $\begin{array}{l}\text { Monoclinic, } \\
P 21 / n\end{array}$ & $\begin{array}{c}\text { Triclinic, } \\
P-1\end{array}$ & $\begin{array}{c}\text { Monoclinic, } \\
C 2 / c\end{array}$ \\
\hline$a, \AA$ & $11.676(3)$ & $12.8290(15)$ & $12.714(3)$ & 17.589(3) \\
\hline$b, \AA$ & $17.369(4)$ & $10.6833(12)$ & 13.882(3) & $11.3015(16)$ \\
\hline$c, \AA$ & $16.657(5)$ & $18.159(2)$ & $16.122(4)$ & 33.974 \\
\hline$\alpha, \operatorname{deg}$ & 90 & 90 & $110.029(3)$ & 90 \\
\hline$\beta, \operatorname{deg}$ & 94.991(17) & $96.773(2)$ & $94.841(3)$ & 102.938(2) \\
\hline$\gamma, \operatorname{deg}$ & 90 & 90 & $110.899(3)$ & 90 \\
\hline$V, \AA^{3}$ & $3365.3(14)$ & $2471.5(5)$ & $2427.3(10)$ & $6582.2(16)$ \\
\hline$Z$ & 4 & 4 & 2 & 16 \\
\hline$\rho_{\text {calc. }}, \mathrm{g} \mathrm{cm}^{-3}$ & 2.047 & 2.145 & 1.810 & 1.772 \\
\hline$\mu, \mathrm{mm}^{-1}$ & 1.793 & 2.235 & 1.372 & 1.270 \\
\hline$T, \mathrm{~K}$ & $150(2)$ & $220(2)$ & $120(2)$ & $100(2)$ \\
\hline $\begin{array}{l}\text { Reflections } \\
\text { collected }\end{array}$ & 23919 & 18517 & 15134 & 45267 \\
\hline $\begin{array}{l}\text { Independent } \\
\text { reflections }\end{array}$ & 3854 & 4850 & 8011 & 8209 \\
\hline $\begin{array}{c}\text { Final R } \\
\text { indices } \\
{[\mathrm{I}>2 \sigma(\mathrm{I})]}\end{array}$ & $\begin{array}{c}\mathrm{R} 1=0.0348 \\
\mathrm{wR} 2= \\
0.0529\end{array}$ & $\begin{array}{c}\mathrm{R} 1=0.0358 \\
\mathrm{wR} 2= \\
0.0700\end{array}$ & $\begin{array}{c}\mathrm{R} 1=0.0570 \\
\mathrm{wR} 2= \\
0.1181\end{array}$ & $\begin{array}{c}\mathrm{R} 1=0.0375 \\
\mathrm{wR} 2= \\
0.0780\end{array}$ \\
\hline AI & 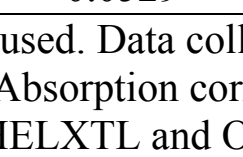 & 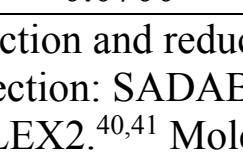 & - & $\begin{array}{l}\text { NT and } \\
\text { ion and } \\
\text { AMOND }\end{array}$ \\
\hline
\end{tabular}


Table 2. Selected bond lengths $(\AA)$ and angles $\left({ }^{\circ}\right)$ for compounds $\mathbf{1 b}, \mathbf{2}, \mathbf{4}$ and $\mathbf{5}$.

\begin{tabular}{|c|c|c|c|}
\hline \multicolumn{2}{|l|}{ 1b } & \multicolumn{2}{|c|}{2} \\
\hline $\operatorname{Pd}(1)-P d(1 \mathrm{~A})$ & $2.7374(8)$ & $\operatorname{Pd}(1)-\operatorname{Pd}(2)$ & $2.7692(6)$ \\
\hline $\operatorname{Pd}(1)-\operatorname{Pd}(2)$ & $2.7858(6)$ & $\operatorname{Pd}(2)-\operatorname{Pd}(3)$ & $2.7404(6)$ \\
\hline $\operatorname{Pd}(2)-P d(1 A)$ & $2.7857(6)$ & $\operatorname{Pd}(3)-\operatorname{Pd}(1)$ & $2.7526(6)$ \\
\hline $\operatorname{Pd}(1)-\mathrm{N}(1)$ & $2.202(3)$ & $\operatorname{Pd}(1)-N(1)$ & $2.186(5)$ \\
\hline \multirow[t]{2}{*}{$\operatorname{Pd}(2)-\mathrm{N}(2)$} & $2.208(4)$ & $\operatorname{Pd}(2)-N(2)$ & $2.145(5)$ \\
\hline & & $\operatorname{Pd}(3)-N(3)$ & $2.155(5)$ \\
\hline $\operatorname{Pd}(1 \mathrm{~A})-\operatorname{Pd}(1)-\operatorname{Pd}(2)$ & $60.571(10)$ & $\operatorname{Pd}(2)-\operatorname{Pd}(1)-\operatorname{Pd}(3)$ & $59.507(16)$ \\
\hline \multirow[t]{2}{*}{$\operatorname{Pd}(1)-\operatorname{Pd}(2)-\operatorname{Pd}(1 \mathrm{~A})$} & $58.86(2)$ & $\operatorname{Pd}(1)-\operatorname{Pd}(2)-\operatorname{Pd}(3)$ & $59.945(16)$ \\
\hline & & $\operatorname{Pd}(2)-\operatorname{Pd}(3)-\operatorname{Pd}(1)$ & $60.548(16)$ \\
\hline \multicolumn{2}{|l|}{4} & \multicolumn{2}{|l|}{5} \\
\hline $\operatorname{Pd}(1)-\operatorname{Pd}(2)$ & $2.7678(13)$ & $\operatorname{Ag}(1)-\mathrm{N}(1)$ & $2.112(3)$ \\
\hline $\operatorname{Pd}(2)-\operatorname{Pd}(3)$ & $2.7626(11)$ & $\operatorname{Ag}(1)-\mathrm{N}(3)$ & $2.117(3)$ \\
\hline $\operatorname{Pd}(3)-\operatorname{Pd}(1)$ & $2.7534(12)$ & $\operatorname{Ag}(2)-N(5)$ & $2.101(3)$ \\
\hline $\mathrm{Pd}(1)-\mathrm{N}(1)$ & $2.180(9)$ & $\operatorname{Ag}(2)-N(7)$ & $2.104(3)$ \\
\hline $\operatorname{Pd}(2)-\mathrm{N}(2)$ & $2.149(9)$ & $\operatorname{Ag}(2)-\operatorname{Ag}(2 i)$ & $3.0344(8)$ \\
\hline $\operatorname{Pd}(3)-N(3)$ & $2.150(9)$ & $\operatorname{Ag}(1)-\operatorname{Ag}(2)$ & 11.295 \\
\hline $\operatorname{Pd}(1)-\operatorname{Pd}(2)-\operatorname{Pd}(3)$ & $59.72(3)$ & & \\
\hline $\operatorname{Pd}(2)-\operatorname{Pd}(1)-\operatorname{Pd}(3)$ & $60.05(3)$ & $\mathrm{N}(1)-\operatorname{Ag}(1)-\mathrm{N}(2)$ & $169.38(11)$ \\
\hline $\operatorname{Pd}(2)-\operatorname{Pd}(3)-\operatorname{Pd}(1)$ & $60.24(3)$ & $\mathrm{N}(3)-\mathrm{Ag}(2)-\mathrm{N}(4)$ & $170.79(10)$ \\
\hline
\end{tabular}




\author{
References \\ 1. $\quad$ Stang, P. J.; Cao, D. H. J. Am. Chem. Soc. 1994, 116, 4981-4982. \\ 2. $\quad$ Seidel, S. R.; Stang, P. J. Acc. Chem. Res. 2002, 35, 972-983. \\ 3. Burgess, S. A.; Kassie, A.; Baranowski, S. A.; Fritzsching, K. J.; Schmidt-Rohr, K.; Brown, C. M.; Wade, \\ C. R. J. Am. Chem. Soc. 2016, 138, 1780-1783. \\ 4. Li, Z.; Schweitzer, N. M.; League, A. B.; Bernales, V.; Peters, A. W.; Getsoian, A. â. œ.; Wang, T. C.; \\ Miller, J. T.; Vjunov, A.; Fulton, J. L. J. Am. Chem. Soc. 2016, 138, 1977-1982. \\ 5. $\quad$ Fairlamb, I. J. S. Org. Biomol. Chem. 2008, 6, 3645-3656. \\ 6. Kapdi, A. R.; Whitwood, A. C.; Williamson, D. C.; Lynam, J. M.; Burns, M. J.; Williams, T. J.; Reay, A. \\ J.; Holmes, J.; Fairlamb, I. J. S. J. Am. Chem. Soc., 135, 8388-8399. \\ 7. Murahashi, T.; Fujimoto, M.; Oka, M.-a.; Hashimoto, Y.; Uemura, T.; Tatsumi, Y.; Nakao, Y.; Ikeda, A.; \\ Sakaki, S.; Kurosawa, H. Science 2006, 313, 1104-1107. \\ 8. $\quad$ Puddephatt, R. J.; Manojlovic-Muir, L.; Muir, K. W. Polyhedron 1990, 9, 2767-2802. \\ 9. $\quad$ Balch, A. L.; Boehm, J. R.; Hope, H.; Olmstead, M. M. J. Am. Chem. Soc. 1976, 98, 7431-7432. \\ 10. Bradford, A. M.; Kristof, E.; Rashidi, M.; Yang, D.-S.; Payne, N. C.; Puddephatt, R. J. Inorg. Chem. 1994, \\ 33, 2355-2363. \\ 11. Rashidi, M.; Kristof, E.; Vittal, J. J.; Puddephatt, R. J. Inorg. Chem. 1994, 33, 1497-1501. \\ 12. Babbini, D. C.; Mulligan, F. L.; Schulhauser, H. R.; Sweigart, T. C.; Nichol, G. S.; Hurst, S. K. Inorg. \\ Chem. 2010, 49, 4307-4312. \\ 13. Mulligan, F. L.; Babbini, D. C.; Davis, I. R.; Hurst, S. K.; Nichol, G. S. Inorg. Chem. 2009, 48, 2708-2710. \\ 14. Babbini, D. C.; Cluff, K. J.; Fisher, N. B.; Charbonneau, J. C.; Nichol, G. S.; Hurst, S. K. J. Organomet. \\ Chem. 2012, 713, 217-221. \\ 15. Murahashi, T.; Usui, K.; Inoue, R.; Ogoshi, S.; Kurosawa, H. Chem. Sci. 2011, 2, 117-122. \\ 16. Crooks, R. M.; Zhao, M.; Sun, L.; Chechik, V.; Yeung, L. K. Acc. Chem. Res. 2001, 34, $181-190$. \\ 17. Scott, R. W. J.; Datye, A. K.; Crooks, R. M. J. Am. Chem. Soc. 2003, 125, 3708-3709. \\ 18. Powell, C. E.; Cifuentes, M. P.; Humphrey, M. G.; Willis, A. C.; Morrall, J. P.; Samoc, M. Polyhedron \\ 2007, 26, 284-289. \\ 19. Green, K. A.; Cifuentes, M. P.; Samoc, M.; Humphrey, M. G. Coord. Chem. Rev. 2011, $255,2025-2038$. \\ 20. Babbini, D. C.; Mulligan, F. L.; Schulhauser, H. R.; Sweigart, T. C.; Nichol, G. S.; Hurst, S. K. Inorg. \\ Chem. 2010, 49, 4307-4312. \\ 21. Babbini, D. C.; Schulhauser, H. R.; Kramer, F. R.; Nichol, G. S.; Hurst, S. K. J. Organomet. Chem. 2011, \\ 696, 3143-3149. \\ 22. Lewis, J. E. M.; Gavey, E. L.; Cameron, S. A.; Crowley, J. D. Chem. Sci. 2011, 3, 778-784. \\ 23. Huck, W. T. S.; Prins, L. J.; Fokkens, R. H.; Nibbering, N. M. M.; van Veggel, F. C. J. M.; Reinhoudt, D. \\ N. J. Am. Chem. Soc. 1998, 120, 6240-6246. \\ 24. Murahashi, T.; Hashimoto, Y.; Chiyoda, K.; Fujimoto, M.; Uemura, T.; Inoue, R.; Ogoshi, S.; Kurosawa, \\ H. J. Am. Chem. Soc. 2008, 130, 8586-8587. \\ 25. Gebauer, T.; Frenzen, G.; Dehnicke, K. In Zeitschrift fur Naturforschung B, 1992; p. 1505. \\ 26. Corbo, R.; Georgiou, D. C.; Wilson, D. J. D.; Dutton, J. L. Inorg. Chem. 2014, 53, 1690-1698. \\ 27. Lewis, J. E. M.; Gavey, E. L.; Cameron, S. A.; Crowley, J. D. Chem. Sci. 2012, 3, 778-784. \\ 28. Murahashi, T.; Nagai, T.; Okuno, T.; Matsutani, T.; Kurosawa, H. Chem. Commun. (Cambridge, U. K.) \\ 2000, 1689-1690. \\ 29. Zopes, D.; Hegemann, C.; Schlaefer, J.; Tyrra, W.; Mathur, S. Inorg. Chem. 2015, 54, 3781-3787. \\ 30. Massoud, A. S. a. A.; Langer, V.; Abu-Youssef, M. A. M. Acta Crystallogr., Sect. C: Cryst. Struct. \\ Commun. 2009, 65, m352-m354. \\ 31. Li, Y.; Dong, X.; Gou, Y.; Jiang, Z.; Zhu, H.-L. J. Coord. Chem. 2011, 64, 1663-1672. \\ 32. Kim, J.; Rees, D. C. Science 1992, 257, 1677-1682. \\ 33. Kruse, S. M.; Hurst, S. K. Tetrahedron Lett. 2015, 56, 6319-6322. \\ 34. Duisenberg, A. J. M.; Kroon-Batenburg, L. M. J.; Schreurs, A. M. M. J. Appl. Crystallogr. 2003, 36, 220- \\ 229. \\ 35. Bruker (2007). SMART, SAINT and APEX Bruker AXS Inc., Madison, Wisconsin, USA. \\ 36. Altomare, A.; Cascarano, G.; Giacovazzo, C.; Guagliardi, A. J. Appl. Crystallogr. 1993, 26, 343-350. \\ 37. Sheldrick, G. Acta Crystallographica Section C 2015, 71, 3-8. \\ 38. (2007). SMART, SAINT and APEX Bruker AXS Inc., Madison, Wisconsin, USA. \\ 39. Sheldrick, G. M. SADABS, University of Göttingen, Germany, 1996. \\ 40. Sheldrick, G. Acta Crystallographica Section A 2008, 64, 112-122.
}


41. Dolomanov, O. V.; Bourhis, L. J.; Gildea, R. J.; Howard, J. A. K.; Puschmann, H. J. Appl. Crystallogr. 2009, 42, 339-341.

42. Brandenburg, K.; Putz, H. (1999). DIAMOND Crystal Impact GbR, Bonn, Germany. 
Tripalladium(0) Sandwich Complexes with Nitrogen Based Ligands

John C. Charbonneau ${ }^{1}$, Cory B. Cluff ${ }^{2}$, Hannah R. Babbini ${ }^{3}$, Dominic C. Babbini ${ }^{3}$, Gary S. Nichol $^{4}$ and Stephanie K. Hurst*1.

Synopsis: The synthesis and characterization of a series of complexes based upon a central tripalladium ditropylium (Tr) unit $\left[\mathrm{Pd}_{3} \mathrm{Tr}_{2}\right]^{2+}$ containing different nitrogen-based ligands is reported. The complexes were synthesized in good yield and characterized by multi-nuclei NMR spectroscopy, elemental microanalysis and single-crystal X-ray crystallography. Variation in the equatorial ligand strongly influences Pd-N bond distances, but has only a minor effect on Pd-Pd distances.

Graphic Abstract:

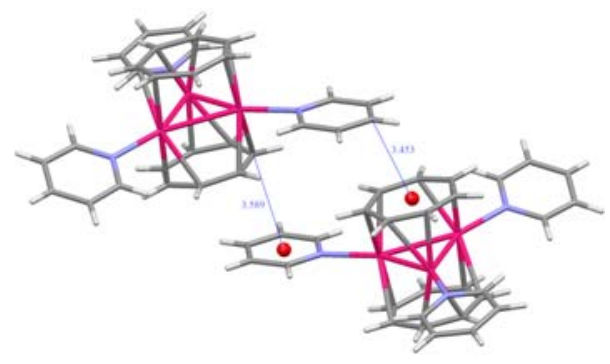


For review purposes only.

\begin{tabular}{|c|c|}
\hline Complex Number & Complex Formula \\
\hline $\mathbf{1 a}$ & {$\left[\mathrm{Pd}_{3} \operatorname{Tr}_{2}\left(\mathrm{Pyridine}_{3}\right]\left[\left(\mathrm{BF}_{4}\right)_{2}\right]\right.$} \\
\hline $\mathbf{1 b}$ & {$\left[\mathrm{Pd}_{3} \operatorname{Tr}_{2}\left(\mathrm{Pyridine}_{3}\right]\left[\left(\mathrm{SO}_{3} \mathrm{CF}_{3}\right)_{2}\right]\right.$} \\
\hline $\mathbf{2}$ & {$\left[\mathrm{Pd}_{3} \operatorname{Tr}_{2}(\mathrm{MeCN})_{3}\right]\left[\left(\mathrm{BF}_{4}\right)_{2}\right]$} \\
\hline $\mathbf{3}$ & {$\left[\mathrm{Pd}_{3} \operatorname{Tr}_{2}(\mathrm{DMAP})_{3}\right]\left[\left(\mathrm{BF}_{4}\right)_{2}\right]$} \\
\hline $\mathbf{4}$ & {$\left[\mathrm{Pd}_{3} \operatorname{Tr}_{2}(\mathrm{DMAB})_{3}\right]\left[\left(\mathrm{SO}_{3} \mathrm{CF}_{3}\right)_{2}\right]$} \\
\hline $\mathbf{5}$ & {$\left[\mathrm{Ag}(\mathrm{DMAP})_{2}\right]\left[\left(\mathrm{BF}_{4}\right)_{3}\right.$} \\
\hline
\end{tabular}


Graphical Abstract

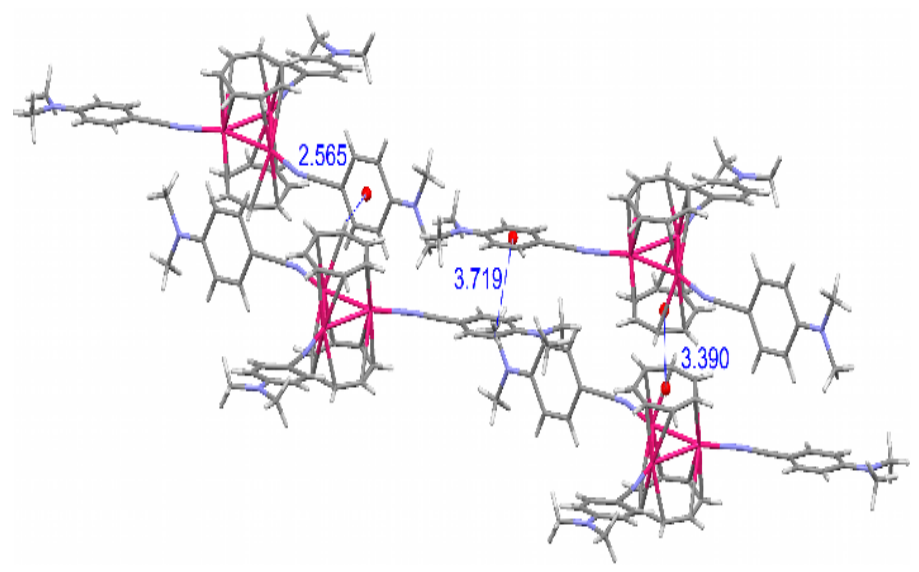

